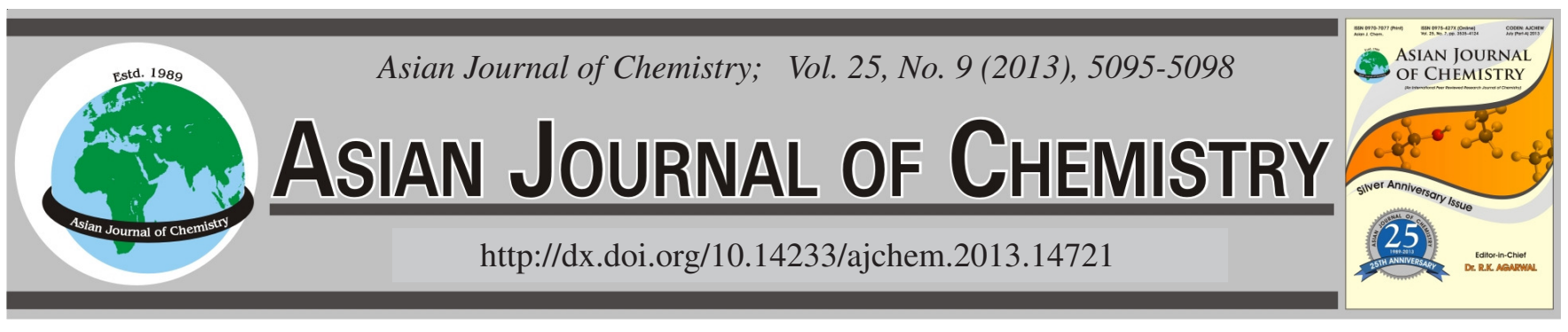

\title{
Influence of the Ionic Liquid Cosolvent on Glucosylation Reactions Catalyzed by $\beta$-Glycosidase for Production of Salidroside
}

\author{
Yanhong Bi, Chun Zhu, Zhaoyu Wang ${ }^{*}$ and JiAnbo JiA
}

School of Life Science and Chemical Engineering, Huaiyin Institute of Technology, Huai'an 223003, P.R. China

*Corresponding author: Tel/Fax: +86 517 83591165; E-mail: biowzy@126.com

\begin{abstract}
The enzymatic synthesis of salidroside catalyzed by $\beta$-glycosidase from Malus pumila seed meal has been successfully carried out in | ionic liquids-containing systems for the first time. The optimum conditions were screened out and the best yield of $24.9 \%$ was received in the $\mathrm{C}_{4} \mathrm{MIm} \cdot \mathrm{PF}_{6}$-containing cosolvent system. Moreover, the influence of ionic liquids on the performance of the enzyme has been discussed, using both hydrophobic and hydrophilic ionic liquids possessing various anions and different alkyl chain lengths (C2-C10) in imidazolium cations.

Key Words: Ionic liquids, Salidroside, Glucosylation, Malus pumila seed meal.
\end{abstract}

\section{INTRODUCTION}

Over the last couple of years, ionic liquids (ILs) have received an ever-increasing attention as biocatalytic reaction media for a wide range of chemical processes, owing to their unique physicochemical properties, such as the environmentally benign nature, recyclability and ability to dissolve both polar and non-polar compounds ${ }^{1}$. For instance, many excellent reviews by Rantwijk et al. ${ }^{2}$, Sowmiah et al. ${ }^{3}$ and Gorke et al. ${ }^{4}$ have manifested the advantages of the ionic liquids-containing enzymatic systems for the purpose of preparing the fine chemicals with markedly high product yield, shorter reaction time, enantioor region-selectivity and better enzyme stability as well.

Glycosides and their analogs, an important group of natural compounds, show multiple biological and pharmacological activities and have been used extensively in food, cosmetics and medicine preparations ${ }^{5}$. Among these compounds, salidroside, mainly obtained from the plant Rhodiola sachalinensis A. Bor., has been reported to have convincing activities in the therapy of inflammation, fatigue, cardiovascular disease and cancer ${ }^{5,6}$. Recently, enzymatic preparation of salidroside has emerged as a promising one-step procedure instead of the tedious isolation and purification steps from the medicinal plant ${ }^{7-9}$, which is on the edge of extinction. However, these biotransformations in synthetic media containing pure organic solvent and buffer solution have traditionally suffered from low product yields ${ }^{10,11}$.

In our previous study, we had successfully performed the $\beta$-glycosidase-catalyzed synthesis of salidroside using unpro- tected and unactivated donors in ionic liquid-containing systems, with a wide range of yields ranging from 4.9-24.5 $\%^{12}$, depending on the nature of the ionic liquids. As a further extension of our research on solvent engineering strategies, the performance of $\beta$-glycosidase from Malus pumila seed meal in ionic liquid-containing systems for producing salidroside was investigated. Additionally, the influence of ionic liquids with various anions and different alkyl chain lengths in cations and was also examined.

\section{EXPERIMENTAL}

1-Butyl-3-methylimidazolium nitrate $\left(\mathrm{C}_{4} \mathrm{MIm} \cdot \mathrm{NO}_{3}\right), \mathrm{N}-$ hexylpyridinium bis(trifluoromethyl sulfonyl) imide $\left(\mathrm{C}_{6} \mathrm{Py} \cdot \mathrm{Tf}_{2} \mathrm{~N}\right)$, 1-butyl-3-methyl imidazolium octylsulfate $\left(\mathrm{C}_{4} \mathrm{MIm} \cdot \mathrm{C}_{8} \mathrm{SO}_{4}\right)$, 1-ethyl-3-methylimidazolium tetrafluoroborate $\left(\mathrm{C}_{2} \mathrm{MIm} \cdot \mathrm{BF}_{4}\right)$, 1-butyl-3-methylimidazolium tetrafluoroborate $\left(\mathrm{C}_{4} \mathrm{MIm} \cdot \mathrm{BF}_{4}\right)$, 1-hexyl-3-methylimidazolium tetrafluoroborate $\left(\mathrm{C}_{6} \mathrm{MIm} \cdot \mathrm{BF}_{4}\right)$, 1-ethyl-3-methylimidazolium hexafluorophosphate $\left(\mathrm{C}_{2} \mathrm{MIm} \cdot \mathrm{PF}_{6}\right)$, 1-butyl-3-methylimidazolium hexafluorophosphate $\left(\mathrm{C}_{4} \mathrm{MIm} \cdot \mathrm{PF}_{6}\right), 1$-hexyl-3-methylimidazolium hexafluorophosphate $\left(\mathrm{C}_{6} \mathrm{MIm} \cdot \mathrm{PF}_{6}\right), 1$-octyl-3-methylimidazolium hexafluorophosphate $\left(\mathrm{C}_{8} \mathrm{MIm} \cdot \mathrm{PF}_{6}\right)$, 1-butyl-3-methylimidazolium chloride $\left(\mathrm{C}_{4} \mathrm{MIm} \cdot \mathrm{Cl}\right)$, 1-butyl-3-methylimidazolium bromide $\left(\mathrm{C}_{4} \mathrm{MIm} \cdot \mathrm{Br}\right), 1$-ethyl3-methylimidazolium iodide $\left(\mathrm{C}_{2} \mathrm{MIm} \cdot \mathrm{I}\right), 1$-propyl-3-methylimidazolium iodide $\left(\mathrm{C}_{3} \mathrm{MIm} \cdot \mathrm{I}\right)$, 1-butyl-3-methylimidazolium iodide $\left(\mathrm{C}_{4} \mathrm{MIm} \cdot \mathrm{I}\right)$, 1-hexyl-3-methylimidazolium iodide $\left(\mathrm{C}_{6} \mathrm{MIm} \cdot \mathrm{I}\right)$, 1-decyl-3-methylimidazolium iodide $\left(\mathrm{C}_{10} \mathrm{MIm} \cdot \mathrm{I}\right)$ and standard salidroside were purchased from Sigma-Aldrich. Malus pumila seeds were obtained from food processing 
company. Tyrosol was from Aladdin. All other chemicals were also from commercial sources and of the highest purity available.

Determination of $\beta$-glycosidase activity: The glucosylation activity of the Malus pumila seed meal was determined as described by our previous report with a specific activity of $23.4 \mathrm{U} / \mathrm{g}^{12}$.

General procedure for enzymatic synthesis of salidroside: In a typical experiment, the mixture $(2.0 \mathrm{~mL})$ of ionic liquid, phosphate buffer (100 mM, pH 6.0) and dioxane containing $0.5 \mathrm{mmol}$ D-glucose, $3.0 \mathrm{mmol}$ tyrosol and 6.0 U Malus pumila seed meal were incubated in a $10 \mathrm{~mL}$ Erlenmeyer shaking flask capped with a septum under predetermined reaction conditions $\left(50^{\circ} \mathrm{C}, 200 \mathrm{rpm}\right)$. Aliquots were withdrawn at specified time intervals from the reaction mixture and then diluted 50 times with corresponding mobile phase prior to HPLC analysis.

HPLC analysis: The reaction mixture was analyzed by RP-HPLC on a $4.6 \mathrm{~mm} \times 250 \mathrm{~mm}(5 \mu \mathrm{m})$ Zorbax SB-C ${ }_{18}$ column (Agilent Technologies Industries Co., Ltd., USA) using an Agilent G1311A pump and a UV detector at $275 \mathrm{~nm}$. The mobile phase is a mixture of water and methanol at a flow rate of $1.0 \mathrm{~mL} / \mathrm{min}$. The volumetric ratio of water to methanol and the retention time for salidroside were $40 / 60$ and $2.47 \mathrm{~min}$.

\section{RESULTS AND DISCUSSION}

Screening the reaction solvent: The nature of the solvent such as polarity, hydrophobicity, dielectric constant and concentration will govern the hydration water of the enzyme molecular, protein conformation change and solubility of the substrate and product, thus affecting the activity, stability and specificity of the enzyme $e^{1,13}$.

As shown in Table-1, among the several pure organic solvents tested, the $\beta$-glycosidase from Malus pumila seed meal displayed the highest yield in dioxane $(12.0 \%)$, moderate yields in THF $(5.0 \%)$ and acetone $(6.8 \%)$ and lower yields in other solvents (1.0-3.3\%). However, the synthetic activity of $\beta$-glycosidase was changed remarkably in co-solvent systems with different ionic liquids as additives than that observed in neat dioxane, suggesting that the nature of the anion in ionic liquid exerts an unexpected effect on the performance of the enzyme. With respect to the initial reaction rates and yields (4.3-10.2\%), $\beta$-glycosidase showed low or moderate activities in dioxane-ionic liquid cosolvents containing $\mathrm{Tf}_{2} \mathrm{~N}^{-}$, $\mathrm{Cl}^{-}, \mathrm{Br}^{-}, \mathrm{NO}_{3}{ }^{-}$and $\mathrm{C}_{8} \mathrm{SO}_{4}{ }^{-}$anions, which seem to have negative effect on the enzyme. For ionic liquid based on $\mathrm{I}^{-}, \mathrm{BF}_{4}^{-}$ and $\mathrm{PF}_{6}{ }^{-}$anions, the higher synthetic activities were obtained with excellent yields (12.4-13.9\%).

The difference in the effects that the various ionic liquids had on the $\beta$-glycosidase may be attributable to several reasons, such as the hydrogen-bond basicity, hydrophilic or hydrophobic property, nucleophilicity of the anion and the viscosity of the ionic liquid ${ }^{2,3}$. In this case, the $\mathrm{C}_{4} \mathrm{MIm} \cdot \mathrm{BF}_{4}$ was considered as the most suitable ionic liquid for the salidroside preparation in cosolvent systems.

Optimization of enzymatic synthesis of salidroside: For a better understanding of the characteristics of the $\beta$-glycosidase in the $\mathrm{C}_{4} \mathrm{MIm} \cdot \mathrm{BF}_{4}$-containing system, several crucial factors influencing the reaction were also studied. Firstly, the impact

\begin{tabular}{|c|c|c|c|}
\hline \multicolumn{4}{|c|}{$\begin{array}{c}\text { TABLE-1 } \\
\text { EFFECT OF SOLVENTS ON ENZYMATIC } \\
\text { SYNTHESIS OF SALIDROSIDE }\end{array}$} \\
\hline Solvents & $\mathrm{V}_{0}(\mathrm{mM} / \mathrm{h})$ & Time (h) & Yield (\%) \\
\hline Acetonitrile & 1.3 & 60 & 3.3 \\
\hline Acetone & 1.2 & 60 & 6.8 \\
\hline THF & 0.4 & 72 & 5.0 \\
\hline tert-Butanol & 0.7 & 72 & 9.3 \\
\hline DMSO & 0.1 & 48 & 2.1 \\
\hline DMF & 0.1 & 48 & 1.0 \\
\hline Dioxane & 1.4 & 72 & 12.0 \\
\hline Dioxane- $\mathrm{C}_{4} \mathrm{MIm} \cdot \mathrm{Br}$ & 1.0 & 56 & 7.6 \\
\hline Dioxane- $\mathrm{C}_{4} \mathrm{MIm} \cdot \mathrm{Cl}$ & 1.0 & 56 & 6.1 \\
\hline Dioxane- $\mathrm{C}_{4} \mathrm{MIm} \cdot \mathrm{I}$ & 1.2 & 72 & 12.4 \\
\hline Dioxane- $\mathrm{C}_{4} \mathrm{MIm} \cdot \mathrm{NO}_{3}$ & 0.9 & 72 & 8.2 \\
\hline Dioxane- $\mathrm{C}_{6} \mathrm{Py} \cdot \mathrm{Tf}_{2} \mathrm{~N}$ & 0.7 & 48 & 4.3 \\
\hline Dioxane- $\mathrm{C}_{4} \mathrm{MIm} \cdot \mathrm{BF}_{4}$ & 1.4 & 72 & 14.8 \\
\hline Dioxane- $\mathrm{C}_{6} \mathrm{MIm} \cdot \mathrm{PF}_{6}$ & 1.4 & 72 & 13.9 \\
\hline Dioxane- $\mathrm{C}_{4} \mathrm{MIm} \cdot \mathrm{C}_{8} \mathrm{SO}_{4}$ & 0.7 & 72 & 10.2 \\
\hline
\end{tabular}

Reaction conditions: 6.0 U Malus pumila seed meal, $0.5 \mathrm{mmol} \mathrm{D}-$ glucose, $2.0 \mathrm{mmol}$ tyrosol, $2.0 \mathrm{~mL}$ organic solvent or dioxane-IL ( $1 \%$, v/v) containing $0.2 \mathrm{~mL}$ phosphate buffer $(100 \mathrm{mM}, \mathrm{pH} 6.2), 50^{\circ} \mathrm{C}, 200$ rpm

of ionic liquid content on both of the initial reaction rate and yield was investigated. As shown in Fig. 1, the enzyme activity was enhanced as the ionic liquid content increased from 0.5 $5.0 \%$. The maximal yield of $16.2 \%$ was observed at $5.0 \%$ of the ionic liquid content and was not further improved by increasing the ionic liquid content (5.0-11.0\%). High ionic strength and the severe dehydration of the enzyme caused by high concentration of hydrophilic $\mathrm{C}_{4} \mathrm{MIm} \cdot \mathrm{BF}_{4}$ might inactivate the enzyme ${ }^{3,4}$, thus leading to poor results. Besides, high viscosity of the reaction mixture resulting from the high ionic liquid concentration can also be proposed as another reason for this phenomenon ${ }^{14}$.

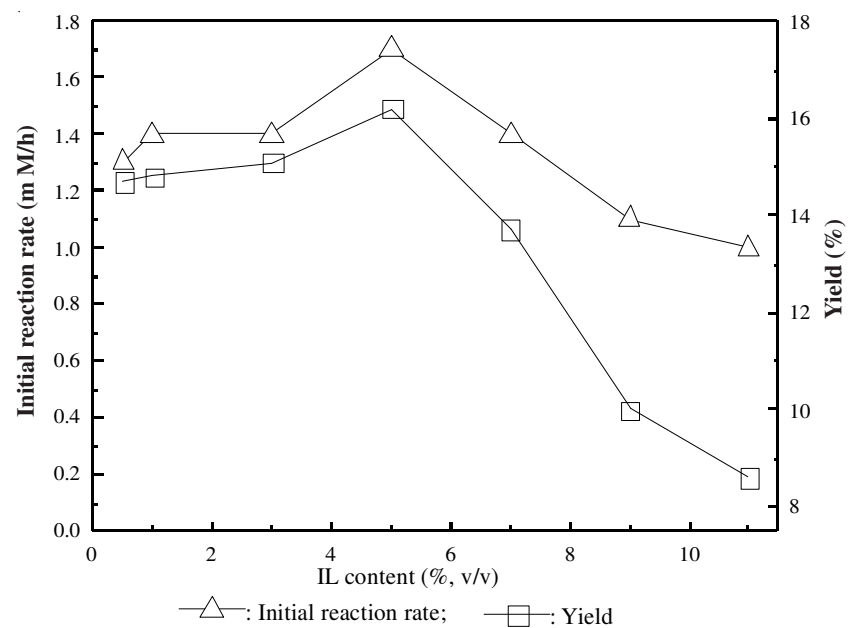

Fig. 1. Effect of ionic liquid content on enzymatic synthesis of salidroside. Reaction conditions: $0.5 \mathrm{mmol} \mathrm{D}$-glucose, $2.0 \mathrm{mmol}$ tyrosol, $6.0 \mathrm{U}$ Malus pumila seed meal, $2.0 \mathrm{~mL}$ solvent containing $0.2 \mathrm{~mL}$ phosphate buffer (100 mM, pH 6.2) and various amounts of $\mathrm{C}_{4} \mathrm{MIm} \cdot \mathrm{BF}_{4}, 50{ }^{\circ} \mathrm{C}, 200 \mathrm{rpm}$

The effect of the buffer $\mathrm{pH}$ on synthetic activity in the ionic liquid-containing cosolvent system is shown in Fig. 2 a. The initial rate and yield were clearly boosted in the $\mathrm{pH}$ range of 5.6-6.0 and then decreased at $\mathrm{pH}$ 6.0-6.6. The highest yield was achieved at pH $6.0(18.3 \%)$. Understandably, buffer 


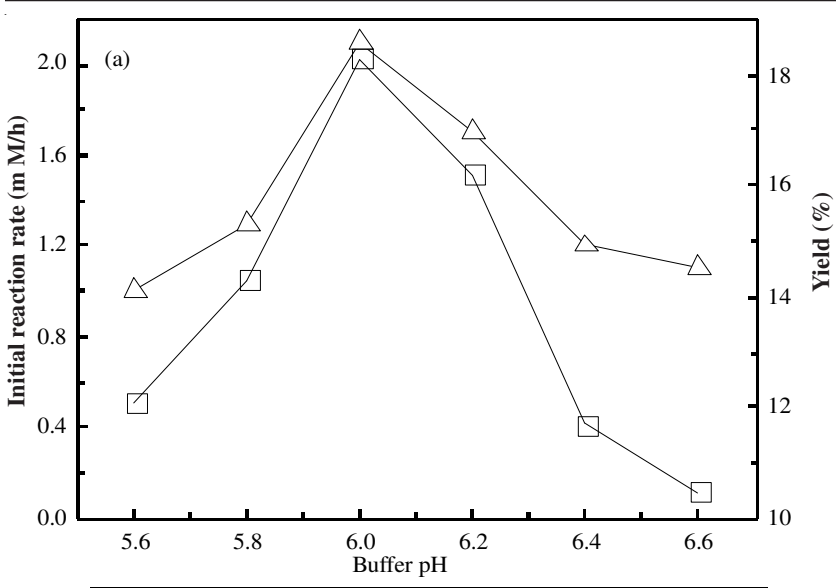

for salidroside synthesis conducted in the $\mathrm{C}_{4} \mathrm{MIm} \cdot \mathrm{BF}_{4}-$ containing system was showed to be 6.0 from the data summarized in Fig. 2c.

Effect of cation chain length of the ionic liquid: In ionic liquid-containing reaction media, it is already well-known that enzyme synthetic activity not only depends on the anion of ionic liquid, but also on the cation ${ }^{15,16}$. To gain a deeper insight into the effect of ionic liquids, the catalytic specificity of the $\beta$-glycosidase on the glucosylation reaction was then examined in media containing methyl imidazolium ionic liquids (MIm) of different cation chain lengths $\left(\mathrm{C}_{\mathrm{n}} \mathrm{MIm}^{+}, \mathrm{n}=2-10\right)$ and in combination with three different anions of $\mathrm{BF}_{4}^{-}, \mathrm{PF}_{6}{ }^{-}$and $\mathrm{I}^{-}$.

Table- 2 showed that although the initial reaction rates were comparable with or lower in 13 ionic liquids-containing cosolvents than that observed in the pure dioxane, the improved yields (20.9-24.9\%) were gained except for those (17.5-17.7 $\%$ ) in $\mathrm{C}_{2} \mathrm{MIm} \cdot \mathrm{I}-$ and $\mathrm{C}_{3} \mathrm{MIm} \cdot \mathrm{I}$-containing systems (Table-2, entries 9-10). This can be partially explained by the higher viscosity stemming from the addition of ionic liquid into the reaction medium, thereby increasing mass transfer resistance ${ }^{15}$.

\begin{tabular}{ccccc}
\multicolumn{5}{c}{ TABLE-2 } \\
\multicolumn{5}{c}{$\begin{array}{c}\text { EFFECT OF THE ILS ON ENZYMATIC } \\
\text { SYNTHESIS OF SALIDROSIDE }\end{array}$} \\
\hline Entry & Ionic liquids & $\mathrm{V}_{0}(\mathrm{mM} / \mathrm{h})$ & Time $(\mathrm{h})$ & Yield $(\%)$ \\
\hline 1 & - & 2.6 & 80 & 19.6 \\
2 & $\mathrm{C}_{2} \mathrm{MIm} \cdot \mathrm{BF}_{4}$ & 2.4 & 84 & 21.9 \\
3 & $\mathrm{C}_{4} \mathrm{MIm} \cdot \mathrm{BF}_{4}$ & 2.6 & 84 & 22.7 \\
4 & $\mathrm{C}_{6} \mathrm{MIm} \cdot \mathrm{BF}_{4}$ & 2.4 & 86 & 21.2 \\
5 & $\mathrm{C}_{2} \mathrm{MIm} \cdot \mathrm{PF}_{6}$ & 2.4 & 84 & 21.5 \\
6 & $\mathrm{C}_{4} \mathrm{MIm} \cdot \mathrm{PF}_{6}$ & 2.7 & 84 & 24.9 \\
7 & $\mathrm{C}_{6} \mathrm{MIm} \cdot \mathrm{PF}_{6}$ & 2.2 & 90 & 20.3 \\
8 & $\mathrm{C}_{8} \mathrm{MIm} \cdot \mathrm{PF}_{6}$ & 2.2 & 90 & 20.2 \\
9 & $\mathrm{C}_{2} \mathrm{MIm} \cdot \mathrm{I}$ & 1.7 & 84 & 17.5 \\
10 & $\mathrm{C}_{3} \mathrm{MIm} \cdot \mathrm{I}$ & 1.7 & 84 & 17.7 \\
11 & $\mathrm{C}_{4} \mathrm{MIm} \cdot \mathrm{I}$ & 2.0 & 90 & 20.9 \\
12 & $\mathrm{C}_{6} \mathrm{MIm} \cdot \mathrm{I}$ & 2.4 & 90 & 22.6 \\
13 & $\mathrm{C}_{10} \mathrm{MIm} \cdot \mathrm{I}$ & 2.4 & 90 & 23.0 \\
\hline
\end{tabular}

Reaction conditions: $0.5 \mathrm{mmol} \mathrm{D}$-glucose, $3.0 \mathrm{mmol}$ tyrosol, $6.0 \mathrm{U}$ Malus pumila seed meal, $0.1 \mathrm{~mL}$ ionic liquids, $0.2 \mathrm{~mL}$ phosphate buffer (100 mM, pH 6.0), $1.7 \mathrm{~mL}$ dioxane, $50{ }^{\circ} \mathrm{C}, 200 \mathrm{rpm}$.

In the case of two widely used ionic liquids based on $\mathrm{BF}_{4}{ }^{-}$ and $\mathrm{PF}_{6}{ }^{-}$anions, an increment in hydrophobic alkyl chain length in imidazolium cation improved synthetic activity up to a maximum, after which declined slightly with the further elongation of the alkyl chain, implying that appropriate chain length of the cation had poor water-stripping ability and low viscosity $^{14,16}$, which were beneficial to maintain the enzyme catalytic activity. Interestingly, the $\beta$-glycosidase showed considerable activity with moderate or good yields (17.5-23.0 $\%$ ) when the $\mathrm{I}^{-}$-based ionic liquids were added into reaction systems. Zhao ${ }^{15}$ has reported that the enzyme performance followed the Hofmeister series in systems involving ionic liquids. In that case, the $\beta$-glycosidase activities should be lower in $\mathrm{I}^{-}$-based ionic liquids than those observed in $\mathrm{Cl}^{-}$- and $\mathrm{Br}^{-}$-based ionic liquids. Clearly, these results were not in accordance with the aforementioned regulation. To our best of knowledge, the unexpected results might be attributed to the hydrogen-bond networks formed from the interaction 
among the ionic liquids, water and substrate, with the exception of the ionic impact of the ionic liquids on the active site of the enzyme.

\section{Conclusion}

The possibility of ionic liquids containing various anions and different alkyl chain lengths in cations as additives in reaction media for the enzymatic production of salidroside catalyzed by $\beta$-glycosidase from Malus pumila seed meal has been demonstrated. The results indicated that the use of ionic liquid as cosolvent brought about a clear change in the performance of the enzyme. Under the optimum conditions, the highest $24.9 \%$ yield was observed when $\mathrm{C}_{4} \mathrm{MIm} \cdot \mathrm{PF}_{6}$ was added into the cosolvent system.

\section{ACKNOWLEDGEMENTS}

This research was sponsored by Qing Lan Project of Jiangsu Province, Natural Science Foundation of Jiangsu Province (No. BK2012243) and Natural Science Research Project of Higher Education of Jiangsu Province (No. 10KJB530001).

\section{REFERENCES}

1. Q.H. Zhang, S.G. Zhang and Y.Q. Deng, Green Chem., 13, 2619 (2011).

2. F. van Rantwijk and R.A. Sheldon, Chem. Rev., 107, 2757 (2007).

3. S. Sowmiah, C.I. Cheng and Y.H. Chu, Curr. Org. Synth., 9, 74 (2012).

4. J. Gorke, F. Srienc and R. Kazlauskas, Biotechnol. Bioprocess Eng., 15, 40 (2011).

5. E.W. Qian, D.T. Ge and S.K. Kong, J. Ethnopharmacol., 133, 308 (2011).

6. X. Chen, J. Liu, X.S. Gu and F. Ding, Brain Res., 1238, 189 (2008).

7. H. Akita, E. Kawahara, M. Kishida and K. Kato, J. Mol. Catal. B, 40, 8 (2006).

8. M.L. Wang and C.X. Guo, Chin. J. Catal., 32, 1051 (2011).

9. R.L. Yang, N. Li and M.H. Zong, J. Mol. Catal. B, 74, 24 (2012).

10. H.L. Yu, J.H. Xu, W.Y. Lu and G.Q. Lin, J. Biotechnol., 133, 469 (2008).

11. W.Y. Lu, G.Q. Lin, H.L. Yu, A.M. Tong and J.H. Xu, J. Mol. Catal. B, 44, 72 (2007)

12. Y.H. Bi, Z.Y. Wang, Y.Y. Mao, S.Y. Zheng, H.J. Zhang and H. Shi, Chin. J. Catal., 33, 1161 (2012).

13. Z. Yang and W. Pan, Enzym. Microbiol. Technol., 37, 19 (2005).

14. H. Zhao, L. Jackson, Z. Song and O. Olubajo, Tetrahedron: Asymm., 17, 2491 (2006).

15. H. Zhao, J. Mol. Catal. B, 37, 16 (2005).

16. T. De Diego, A. Manjón, P. Lozano, M. Vaultier and J.L. Iborra, Green Chem., 13, 444 (2011). 